\title{
Two new species of Ainudrilus (Clitellata: Tubificidae) from south-western Australia, with notes on Ainudrilus nharna Pinder and Brinkhurst
}

\author{
Adrian M. Pinder and Stuart A. Halse \\ Department of Conservation and Land Management, P.O. Box 51, Wanneroo, 6946 Western Australia, Australia
}

\begin{abstract}
Abtsract - Two new species of Ainudrilus are described from south-western Australia and the description of A. nharna is amended. Ainudrilus angustivasa sp. nov., from Lake Logue near Eneabba, is characterised by simple spermathecal ducts, thin vasa deferentia and lack of hair chaetae. Ainudrilus ngopitchup sp. nov., from a swamp near Kojonup, has long spermathecal ducts, broad vasa deferentia and hair chaetae.
\end{abstract}

\section{INTRODUCTION}

The freshwater representatives of the tubificid genus Ainudrilus were recently reviewed by Pinder and Brinkhurst (2000). Four freshwater species, all from Australia and numerous marine species, from Australia and elsewhere in the Pacific and Caribbean, are currently recognised (Erséus, 1990, 1997; Finogenova, 1982). Two new species have recently been collected from freshwater wetlands sampled during a biological survey of the wheatbelt and adjacent coastal areas of southwestern Australia. Wetlands in this region are threatened by secondary salinisation and waterlogging resulting from rising groundwater caused by replacement of perennial native vegetation by annual crops that use less water (George et al., 1995). The biological survey is designed to provide a framework for planning the conservation of regional biodiversity in the face of this threat. Non-marine tubificids are particularly sensitive to salinity and discovery of two new species in the south-west, which otherwise has only one endemic tubificid (Ainudrilus nharna Pinder and Brinkhurst, 2000), is of conservation significance in relation to the above environmental concerns.

\section{MATERIALS AND METHODS}

The two new species were collected in samples of benthic invertebrates taken using a $D$-frame sweep net with a mesh pore size of $250 \mu \mathrm{m}$ and preserved in ethanol. Specimens were stained with Grenacher's borax carmine, cleared with methyl salicylate and slide mounted in Permount ${ }^{\circledast}$, either whole or with the genital segments dissected. Type material is deposited with the Western Australian Museum (WAM) with other material held by the Department of Conservation and Land Management (CALM).

\section{SYSTEMATICS}

\section{Subfamily Rhyacodrilinae}

Genus Ainudrilus Finogenova, 1982

\section{Type species}

Ainudrilus oceanicus Finogenova, 1982 by original designation.

\section{Diagnosis}

Hair chaetae present or absent. Chaetae of penial segment modified, chaetae of spermathecal segment usually unmodified. Vasa deferentia usually broad and glandular, entering atria medially to subapically. Atria variably shaped but usually more or less erect or directed posteriad, consisting of an ampulla, often constricted medially and with spacious lumen, often containing sperm, usually leading to well developed ejaculatory ducts. Prostate absent. Penes absent, though ejaculatory ducts often eversible. Spermathecae with distinct, and often complex ducts. Sperm loose in spermathecal ampullae. Coelomocytes large and generally abundant.

Included Australian freshwater species: Ainudrilus fultoni (Brinkhurst, 1982), A. billabongus (Brinkhurst, 1984), A. stagnalis Erséus, 1997, A. nharna Pinder and Brinkhurst, 2000, A. angustivasa sp. nov. and A. ngopitchup sp. nov.

\section{Ainudrilus nhama Pinder and Brinkhurst, 2000} Figure 1

Ainudrilus nharna Pinder and Brinkhurst, 2000: 55, Figure 3.

\section{Material examined}

Holotype and Paratypes

Frankland River at Roe Road ford, 34 km NNW 

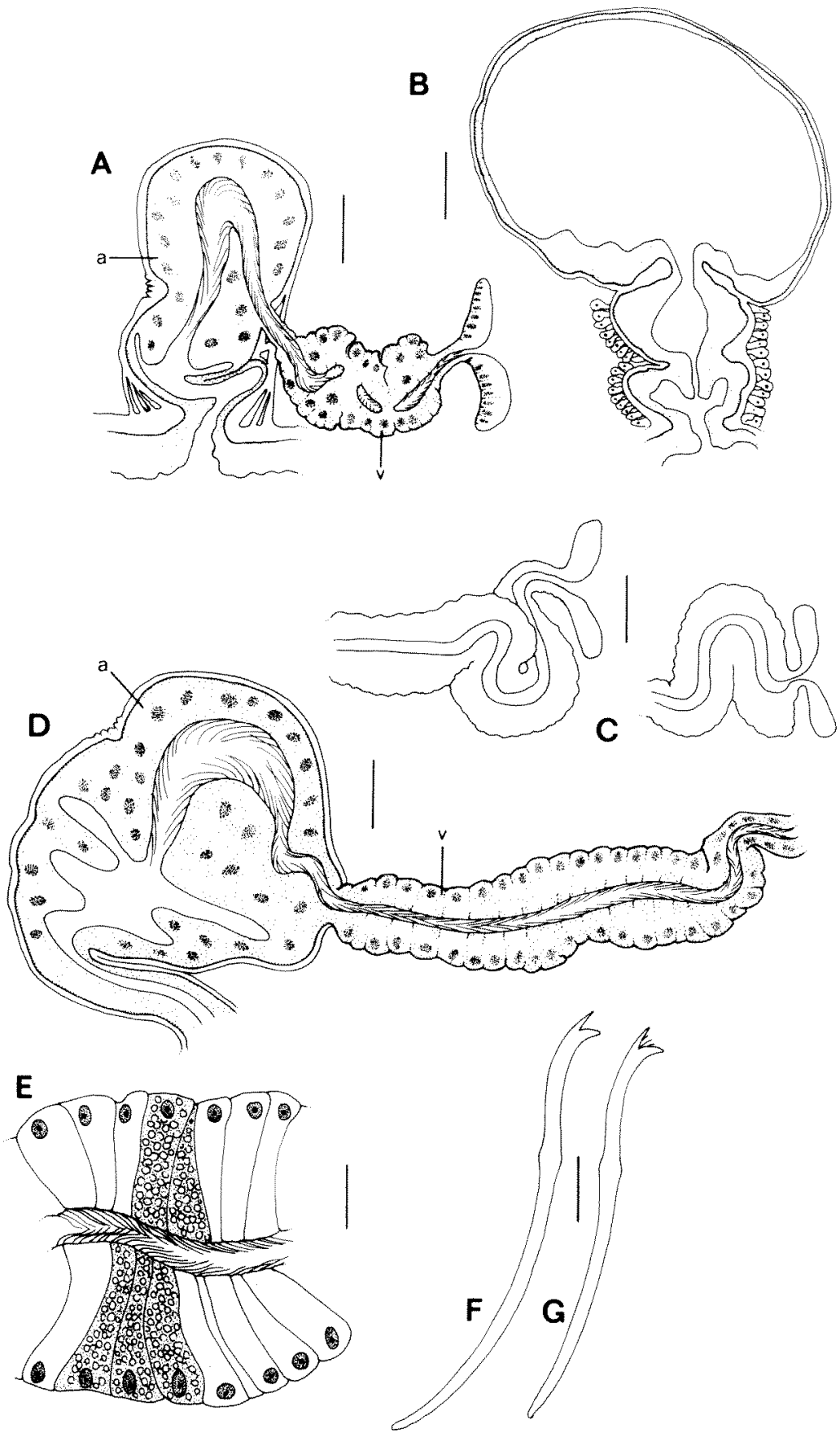

Figure 1 Ainudrilus nharna Pinder and Brinkhurst: A, male genitalia of holotype; B, spermatheca of holotype; C, folded vasa deferentia of WAM V4159 and V4166; D, male genitalia from WAM 37-98; E, section through vas deferens of WAM V4156, showing glandular nature of lining cells; F, ventral chaeta; G, dorsal chaeta. Scale lines: A-D $50 \mu \mathrm{m} ; E-G, 20 \mu \mathrm{m}$.

of Walpole, Western Australia, 34\% $41^{\prime} 02^{\prime \prime S}$ 116 51 '13"E, 9 September 1996 (WAM 1-99 to 4-99).

\section{Other Material}

Not previously listed. All specimens from the south-west of Western Australia, collected by the authors with D.J. Cale or J.M. McRae and held by CALM. Calyerup Creek, west of Fitzgerald River National Park, 3356'11"S 119 03'56"E, 12 September 1998; Dale River at Lupton's Bridge, $32^{\circ} 18^{\prime} 08^{\prime \prime} \mathrm{S}$ $116^{\circ} 41^{\prime} 16^{\prime \prime E}, 29$ October 1997; Dam on Gorge Rock,
SE of Corrigin, $32^{\circ} 27^{\prime} 29^{\prime \prime S} 117^{\circ} 59^{\prime} 53^{\prime \prime} \mathrm{E}, 22$ October 1997; Hamersley River, Fitzgerald River National Park, 3353'25"S 11951'39"E, 12 September 1998; Jimperding Brook at Lover's Lane, $31^{\circ} 35^{\prime} 32^{\prime \prime} \mathrm{S}$ $116^{\circ} 21^{\prime} 43^{\prime \prime E}, 28$ October 1997; Lake Bryde, $30 \mathrm{~km}$ SW of Newdegate, 33 $21^{\prime} 14^{\prime \prime} \mathrm{S} 118^{\circ} 49^{\prime} 26^{\prime \prime} \mathrm{E}, 3$ October 1997; Lake Coomelberrup, $10 \mathrm{~km} \mathrm{SE}$ of Dumbleyung, 33⒉'36"S $117^{\circ} 47^{\prime} 01^{\prime \prime} \mathrm{E}, 05$ Nov 1998; Lake Dulbining, $40 \mathrm{~km} \mathrm{E}$ of Narrogin, $32^{\circ} 54^{\prime} 24^{\prime \prime} \mathrm{S}$ $117^{\circ} 36^{\prime} 49^{\prime \prime} \mathrm{E}, 24$ October 1997; Melaleuca swamp 30 $\mathrm{km}$ NW of Hopetoun, $33^{\circ} 49^{\prime} 40^{\prime \prime} \mathrm{S} 120^{\circ} 24^{\prime} 20^{\prime \prime} \mathrm{E}, 11$ 
September 1998; Melaleuca swamp in Paperbark Nature Reserve, $21 \mathrm{~km}$ SE of Corrigin, 32 24'58"S 118 $05^{\prime} 51^{\prime \prime E}, 25$ October 1999; Peenebup Creek, 10 $\mathrm{km} \mathrm{S}$ of Ongerup, $34^{\circ} 06^{\prime} 02^{\prime \prime S} 118^{\circ} 32^{\prime} 12^{\prime \prime} \mathrm{E}, 27$ September 1998; Lake Pleasant View, Manypeaks, 3449'51"S 118¹0'59"E, 29 September 1998.

Material listed in Pinder and Brinkhurst (2000) newly deposited with WAM. Thomas Spring,

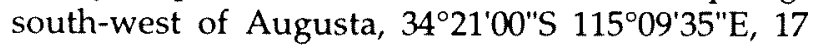
September 1996 (WAM V4159); northern tributary of Collier Creek on Cemetary Road, Walpole, 34 $58^{\circ} 30^{\prime \prime} \mathrm{S} 116^{\circ} 45^{\prime} 12^{\prime \prime} \mathrm{E}, 11$ September 1996 (WAM 4160); Frankland River at Roe Road Ford, 34 41'02"S 116 51 '13"E, 9 September 1996 (WAM V4156-4158).

\section{Remarks}

This species was described and illustrated in Pinder and Brinkhurst (2000) but re-examination of new and previously documented material has revealed some new features and intra-specific variation for some characters. Pinder and Brinkhurst (2000) noted 4-7 penial chaetae per bundle but up to 10 per bundle have now been observed. As noted for the two new species, one or both of the spermathecal ampullae of $A$. nharna sometimes lie in IX, though still with pores anteriorly on $X$. The vasa deferentia of this species are ciliated, with the lining tissue consisting of a single layer of tall cells filled with vacuoles (Figure $1 E$ ) indicating glandular activity. The lumen of the vasa deferentia is generally difficult to follow and was wrongly interpreted as being folded vertically in the holotype (partly because of confusion with the ovary, which is normally closely associated with the vas deferens) but is actually only slightly folded horizontally (Figure 1A). The vasa deferentia vary from fairly straight (Figure 1D) to moderately folded (Figure 1C) in dissected specimens. The atria of the sectioned holotype appear fairly erect (Figure $1 \mathrm{~A})$, whereas in dissected and slide mounted specimens (e.g. Figure 1E), including specimens collected with the holotype, the atria appear more squashed. This is probably due to compression under the coverslip, although the lower part of the atrium and the ejaculatory duct appear to be eversible (seen protruding from the male pore in some specimens) so the shape of the atria will depend on the degree of contraction. Despite the real or apparent plasticity of the shape and arrangement of the atrium and vas deferens, all specimens attributed to $A$. nharna have the characteristic short spermathecal duct with the constriction close to the pore (Figure 1B), and have chaetae of the same size and form (Figure 1G, H) and so are considered to be conspecific.

A record of this species from Lake Walbyring near Narrogin (Pinder and Brinkhurst, 2000) was considered to be a northern outlier from other records listed in the same publication, but the new records listed above show that the species is widespread in the south-west, including the central and southern wheatbelt and south-coast and occurs in a wide variety of wetlands. Pinder and Brinkhurst (2000) noted that A. nharna was present at Lake Walbyring when this wetland had a salinity of 2.8 parts per thousand (ppt) (Halse et al., 2000) but was apparently absent at a later date when salinity was $20 \mathrm{ppt}$. However, the species was subsequently collected at Lake Coomelberrup and Hamersely River at salinities of 22 and 20 ppt respectively and is evidently tolerant of moderate salinity.

\section{Ainudrilus angustivasa sp. nov. Figure 2}

\section{Material examined}

\section{Holotype}

Dissected specimen, Lake Logue, $12 \mathrm{~km}$ SSW of Eneabba in Lake Logue Nature Reserve, 29 $59^{\prime} 20^{\prime \prime} \mathrm{S}$ 11508'50"E, Western Australia, 27 October 1999, S.A. Halse and D.J. Cale (WAM V4145).

\section{Paratypes}

Five on slides ( 1 dissected, 4 whole-mounted) and several matures and immatures in alcohol, collection data as for holotype (WAM V4147-4153).

\section{Etymology}

From the latin angustus (narrow), referring to the thin vasa deferentia.

\section{Description}

Dimensions of preserved and slide-mounted specimens: length $7.5-9 \mathrm{~mm}$, width $0.45-0.5 \mathrm{~mm}$. Number of segments 42-54. Prostomium rounded. Pharynx in II and III, pharyngeal gland cells abundant, mostly on pharynx and oesophagus rather than post-pharyngeal septa. Oesophagus from pharynx to IX, stomach in X-XII (type specimens with numerous parasitic ciliates attached to interior of stomach wall). Coelomocytes patchily distributed, particularly abundant in some preclitellar segments, ovoid (10-15 $\mu \mathrm{m})$ and granulated. Clitellum covering posterior third of $X$ and all of XI and XII, least developed ventrally on $X I$.

Hair chaetae absent, all chaetae bifid with upper teeth slightly shorter than lower, nodulus distal. Ventral and dorsal chaetae from II, 65-75 $\mu \mathrm{m}, 6-9$ per bundle anteriorly, 3-5 per bundle posteriorly. Penial chaetae of XI 4-8 per bundle, 65-87 $\mu \mathrm{m}$, with simple bent ectal ends (some bifid on semimature specimens) and indistinct distal nodulus. Penial chaetae lying in a line parallel to each other and protruding through the body wall ventral to 


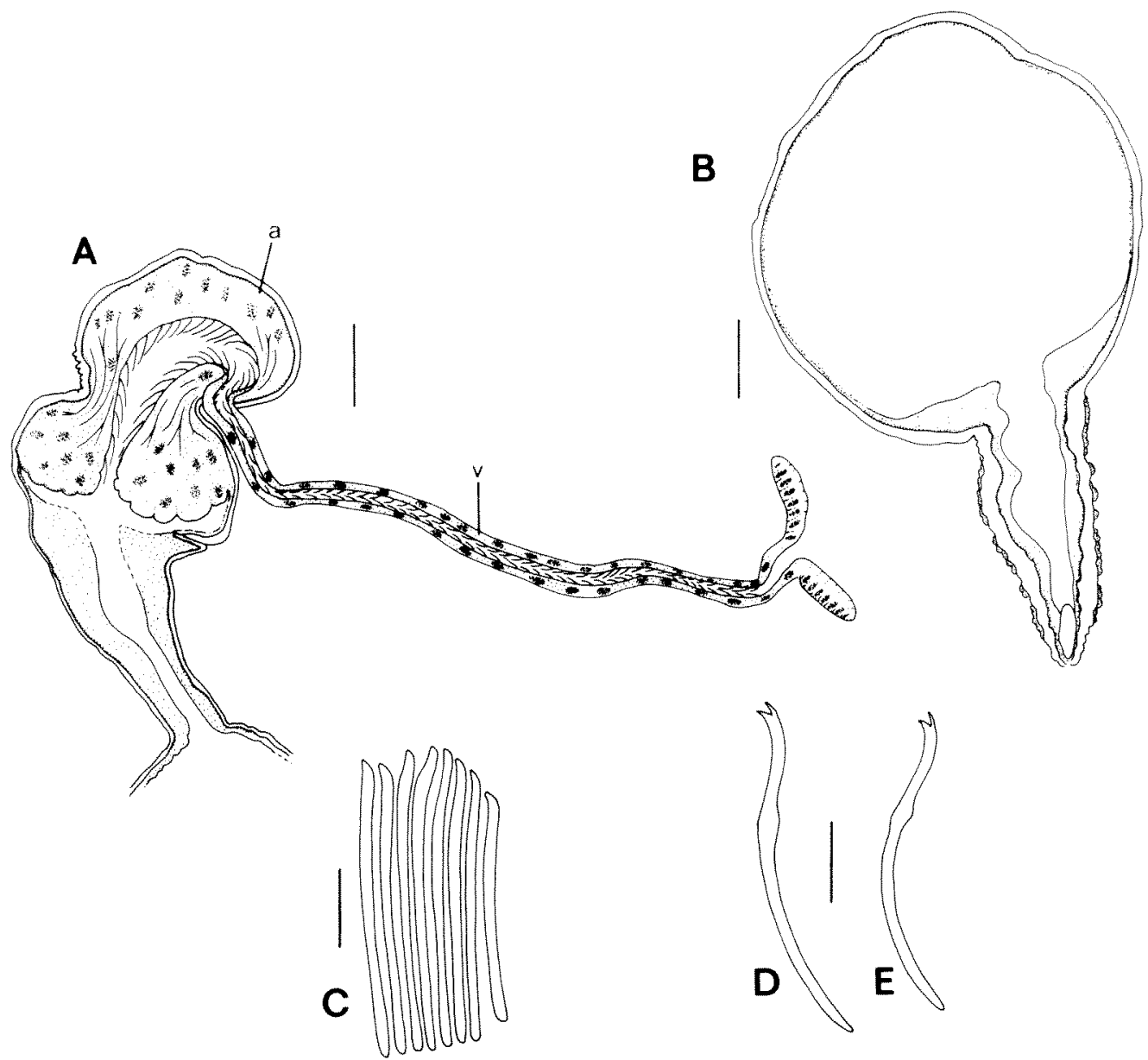

Figure 2 Ainudrilus angustivasa sp. nov.: A, male genitalia of holotype; B, spermatheca of holotype; C, penial chaetae; $D$, ventral chaeta; $E$, dorsal chaeta. Scale lines: A-B $50 \mu \mathrm{m} ; C-E, 20 \mu \mathrm{m}$.

male pores. Chaetae on spermathecal segment present but not modified.

Genitalia paired. Genital pores in line with somatic ventral chaetae, spermathecal pores anterior on X, male pores medial on XI. Male pores each a narrow slit within longitudinal depressions either side of penial chaetae. Testes and ovaries antero-ventral in $X$ and $X I$ respectively. Sperm sacs to VIII and XVII, egg sacs to XV. Spermathecal ampullae ovoid in $\mathrm{XX}$ and/or $X, 210-225 \mu \mathrm{m}$ long, containing loose sperm, connected to pores on $\mathrm{X}$ via muscular ducts $(130-150 \times 65-80 \mu \mathrm{m})$. Ratio of length of spermathecal ampulla to duct length about 1:0.75. Ducts with lining tissue surrounded by thick circular muscle, with sparse covering of peritoneal cells. Sperm funnels on $10 / 11$ feed narrow $(14-19 \mu \mathrm{m})$ non-glandular ciliated vasa deferentia which enter atria medially. Atria 115-145 $\mu \mathrm{m}$ wide, in two parts separated by a ring of atrial muscle around the middle, upper part with thick lining tissue around broad ciliated lumen, lower part with thick lining tissue around narrower ciliated lumen, except for a more open unciliated area ectally near ejaculatory ducts. Atrial lumen not containing sperm in type material. Eversible ejaculatory ducts narrowing between atria and pores (everted in some specimens). Prostate tissue absent. Female pores not observed.

\section{Remarks}

The lack of prostate tissue, medial entry of the vas into the atria and the bipartite atria are typical of the genus Ainudrilus and the numerous parallel penial chaetae are at least similar to the other freshwater forms (marine species generally have fewer, except for the type species $A$. oceanicus). The narrow vasa deferentia are unusual but also known in the marine Ainudrilus lutulentus (Erséus, 1984) of southern China, which was attributed to this genus by Erséus (1990) because it is 'otherwise similar to the type species' (i.e. it lacks prostate and the vas/ atrial union is not apical). Rhyacodrilus simplex (Benham, 1903) of New Zealand also lacks prostates, which are normally present as a diffuse covering over the atria in Rhyacodrilus, and has thin, non-glandular vasa deferentia but the latter curl around the atrium and enter it more apically. Ainudrilus angustivasa differs from the remaining two species from Western Australia in the lack of hair chaetae and can be distinguished from other 
Australian freshwater species, which all lack hairs, by the thin vasa deferentia and the morphology of the other chaetae, see Brinkhurst $(1982,1984)$ and Erséus (1997).

Lake Logue is a fresh to brackish lake fringed by Melaleuca and Acacia trees. It usually dries seasonally, although occasionally contains water for several years. At the time of sampling the water was moderately coloured at $280 \mathrm{TCU}, \mathrm{pH}$ was 7.83 to 8.18 and salinity was $1.1 \mathrm{ppt}$.

\section{Ainudrilus ngopitchup sp. nov.} Figure 3

\section{Material examined}

\section{Holotype}

Dissected specimen, Ngopitchup Swamp, in Water Reserve 2184, $21.5 \mathrm{~km}$ south-west of Kojonup, 3357'27'S 117 20'32"E, Western Australia, coll. A.M. Pinder and J.M. McRae (WAM V4154).

\section{Paratype}

Whole-mounted specimen, collection details as for holotype (WAM V4155).

\section{Etymology}

Named for the type locality.

\section{Description}

Both specimens with post-clitellar segments missing so length unknown. Width of slide mounted specimens at IX $0.34 \mathrm{~mm}$ (holotype) and $0.46 \mathrm{~mm}$ (paratype). Prostomium rounded. Pharynx in II and III, pharyngeal gland cells mostly on pharynx and oesophagus in IV-VI. Oesophagus from pharynx to IX, stomach in X-XII. Coelomocytes sparse, ovoid (about $10 \mu \mathrm{m}$ long) and granulated. Clitellum from $1 / 2 X$ to end of XII.

Anterior ventral chaetae $4-6$ per bundle from II, 85-100 $\mu \mathrm{m}$, bifid with upper tooth thinner and slightly shorter than upper, nodulus distal. Anterior dorsal bundles each with 4-5 long (235-330 $\mu \mathrm{m}$ ) thin hairs and an equal number of crotchet chaetae of similar dimensions and form to ventral chaetae but with fine pectinations on some. Penial chaetae of XI 3-5 per bundle with simple bent ectal ends, about same length as somatic ventral chaetae, lying in parallel to each other and protruding through the body wall ventral to the male pores. Chaetae on spermathecal segment present but not modified.

Genitalia paired. Genital pores in ventral chaetal line. Spermathecal pores anterior on X, male pores medial on XI. Male pores each a narrow slit in depression lateral to penial chaetae. Testes and ovaries antero-ventral in $\mathrm{X}$ and $\mathrm{XI}$ respectively. Spermathecal ampullae ovoid, 210-260 $\mu \mathrm{m}$ long with loose sperm, connected to pores via long muscular ducts $(245-330 \times 50-75 \mu \mathrm{m})$, ratio of ampulla to duct about $1: 1.3$. Duct with narrow lumen, surrounded by thick lining tissue then circular muscle and a continuous layer of peritoneal cells. Junction of duct and spermathecal ampulla particularly muscular with circular muscle forming a sphincter just ectal to duct-ampulla union. Spermathecal ducts of paratype penetrating septa $9 / 10$ and $10 / 11$, with one ampulla in IX and one in XI. Holotype with at least one ampulla in XI prior to dissection. Sperm funnels on 10/11 feed broad (up to $50 \mu \mathrm{m}$ ) ciliated, possibly glandular, loosely folded vasa deferentia. Exact position of atrium/ vas deferens union not visible but presumably medial. Atria $85-120 \mu \mathrm{m}$ wide, in two parts separated by a ring of muscle tissue, ental part with thick lining tissue around a broad ciliated lumen and ectal part with upper half filled with lining tissue around narrow ciliated lumen and lower half forming a broad unciliated lumen. Atria without sperm in type specimens. Ejaculatory ducts narrowing towards pores. Prostate tissue absent. Female pores not observed.

\section{Remarks}

The lack of prostate tissue, broad vasa deferentia and the bipartite atria are all typical of the genus Ainudrilus. The only other Ainudrilus to possess hair chaetae are A. nharna and three marine species (Ainudrilus brendae Erséus, 1997, Ainudrilus piliferus Erséus, 1997 and Ainudrilus taitamensis Erséus, 1990). The marine species differ from both $A$. ngopitchup and $A$. nharna in that $A$. brendae has only two small straight penial chaetae per bundle and has ventral chaetae with upper teeth much longer than the lower, and the other two have long tubular atria. The long spermathecal ducts readily distinguish the new species from $A$. nharna. The chaetae of $A$. ngopitchup are also slightly shorter than those of $A$. nharna.

The type locality, Ngopitchup Swamp, is a shallow perched seasonal sedge swamp with sandy clay sediment. At the time of sampling the water was moderately coloured at $280 \mathrm{TCU}$, pH was 8.47 and salinity was $0.58 \mathrm{ppt}$.

\section{DISCUSSION}

Apomorphies uniting species of Ainudrilus are the lack of prostate (presumably lost independently in Rhyacodrilus simplex and other genera) and the nonapical entry of the vasa deferentia into the atria. The type species, $A$. oceanicus, has vasa deferentia lining cells that are clearly glandular, as in $A$. nharna, which suggested to Baker (1982) that this species was not closely related to $A$. fultoni (then in Rhyacodrilus) and Rhyacodrilus simplex, which he observed to have non-glandular vasa deferentia. Rhyacodrilus fultoni was transferred to Ainudrilus by 


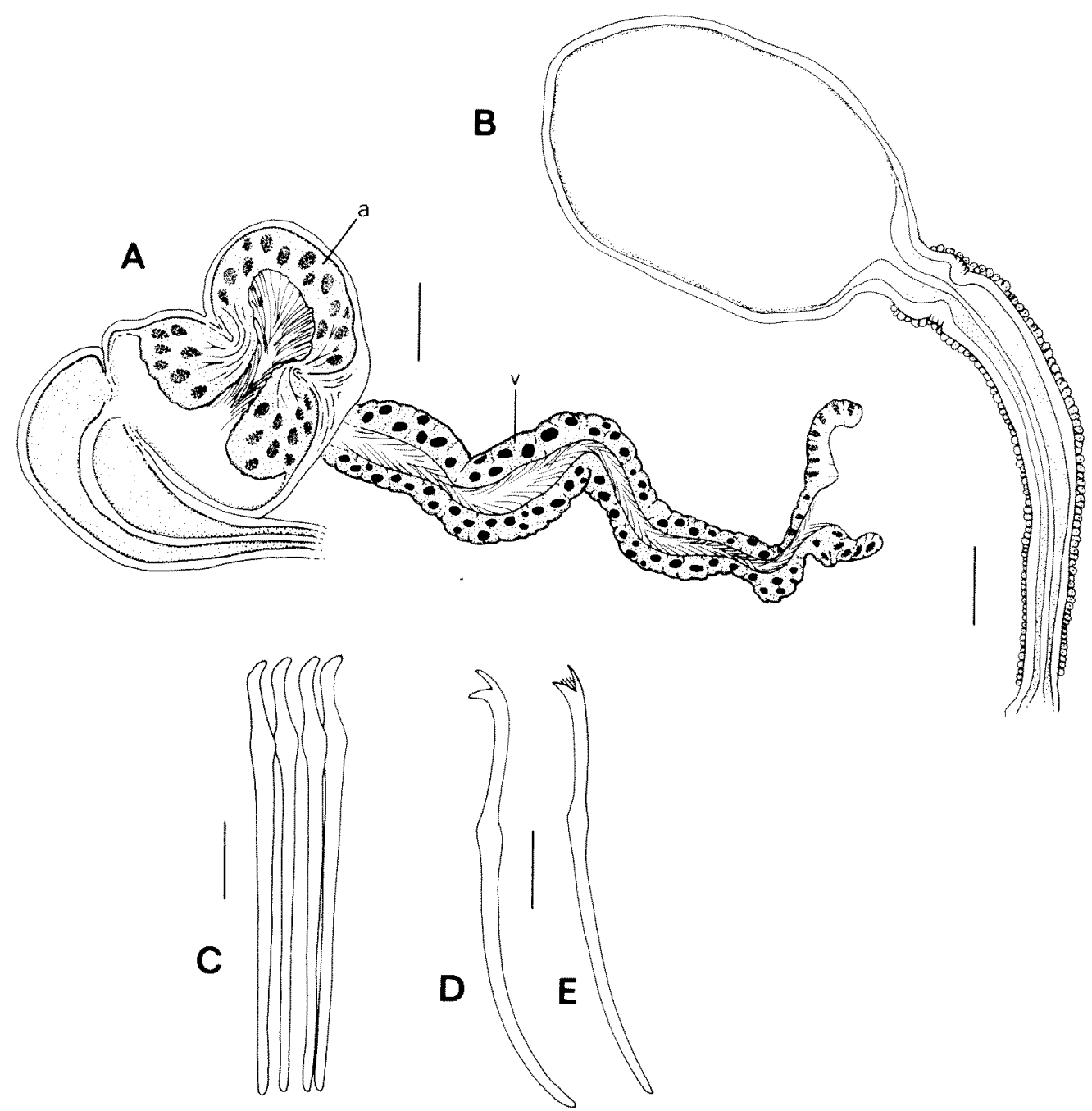

Figure 3 Ainudrilus ngopitchup sp. nov: A, male genitalia of holotype; B, spermatheca of holotype; C, penial chaetae; $D$, ventral chaeta; $E$, dorsal chaeta. Scale lines: A-D $50 \mu \mathrm{m} ; E-G, 20 \mu \mathrm{m}$.

Erséus (1990) on the basis of its lack of prostate and non-apical atrial vas/union. Other species $(A$. lutulentus and $A$. gibsoni) with these features, but also with vasa deferentia that are not clearly glandular, have now also been included in the genus (Erséus, 1990). In fact, $A$. fultoni has vasa deferentia with an amorphous appearance, due to the thick lining tissue, and thus appears intermediate in form between $A$. angustivasa and $A$. nharna/A. oceanicus, whether glandular or not. Baker suggested that $A$. oceanicus has atria with thin lining tissue because the glandular role normally performed by the atrial cells was being performed by the vasa deferentia. However, $A$. nharna, which also has clearly glandular vasa deferentia (Figure $1 \mathrm{~F})$, has atrial lining tissue as well developed as that of $A$. angustivasa which has a thin, non-glandular vasa deferentia. This suggests that there is no correlation between the glandular development of the atria and vasa deferentia.

Both of the new species are known from single freshwater localities in the agricultural south- west of Western Australia, where a large proportion of freshwater wetlands are threatened or already affected by secondary salinisation and hydrological disturbance. The salinity tolerances of the new species are unknown but both appear to be uncommon compared to A. nharna, which has been found in many wetlands and rivers throughout the southwest and is known to occur in water up to $22 \mathrm{ppt}$. Neither of the localities for the new species (Ngopitchup Swamp and Lake Logue) is threatened by salinity, as the former is perched above the surrounding landscape and the latter lies in a coastal sandplain with low salinity groundwater. However, the new species highlight the conservation value of wetlands, such as these, that are likely to maintain a diverse freshwater fauna in a region broadly affected by salinity.

\section{ACKNOWLEDGEMENTS}

The biological survey of the wheatbelt is part of 
the State Salinity Strategy. Field work was undertaken with Jane McRae and David Cale and samples were sorted by Jane McRae, Melitta Pennifold and Edyta Jasinska. We thank Ralph Brinkhurst and Christer Erséus for advice about the gut protozoa in A. angustivasa.

\section{REFERENCES}

Baker, H.R. (1982). Vadicola aprostatus gen. nov., sp. nov., a marine oligochaete (Tubificidae; Rhyacodrilinae) from British Columbia. Canadian Journal of Zoology 60: $3232-3236$.

Benham, W.B. (1903). On some new species of aquatic Oligochaeta from New Zealand. Proceedings of the Zoological Society of London 2: 202-232.

Brinkhurst, R.O. (1982). Additional aquatic Oligochaeta from Australia and New Zealand. Records of the Queen Victoria Museum 78: 1-13.

Brinkhurst, R.O. (1984). Two new species of Tubificidae (Oligochaeta) from the Northern Territory of Australia. Proceedings of the Biological Society of Washington 97: 142-147.

Erséus, C. (1984). The marine Tubificidae (Oligochaeta) of Hong Kong and Southern China. Asian Marine Biology 1: 135-175.

Erséus, C. (1990). Marine Oligochaeta of Hong Kong. In Morton, B. (ed.) The Marine Flora and Fauna of Hong Kong and Southern China. Proceedings of the Second International Marine Biological Workshop 259-334. Hong Kong University Press, Hong Kong.
Erséus, C. (1997). The marine Tubificidae (Oligochaeta) of Darwin Harbour, Northern Territory, Australia, with descriptions of fifteen new species. In Hanley, J.R., Caswell, G., Megirian, D. and Larson, H.K. The Marine Flora and Fauna of Darwin Harbour, Northern Territory, Australia. Procedings of the Sixth International Marine Biological Workshop 99-132. Museums and Art Galleries of the Northern Territory and the Australian Marine Sciences Association, Darwin.

Finogenova, N.P. (1982). Ainudrilus oceanicus, novyi rod i vid semeistva Tubificidae (Oligochaeta). Zoologicheskii Zhurnal 61: 1255-1258.

George, R.J., McFarlane, D.J. and Speed, R.J. (1995). The consequences of a changing hydrologic environment for native vegetation in southwestern Australia. In Saunders, D. A., Craig, J. L. and Mattiske, E. M. (eds) Nature Conservation 4: The Role of Networks 9-22. Surrey-Beatty, Sydney.

Halse, S.A., Pearson, G.P. McRae, J.M. and Shiel, R.J. (2000). Monitoring aquatic invertebrates and waterbirds at Lake Toolibin and Walbyring Lakes in the Western Australian wheatbelt. Journal of the Royal Society of Western Australia 83: 17-28.

Pinder, A.M. and Brinkhurst, R.O. (2000). A review of the Tubificidae (Annelida: Oligochaeta) from Australian inland waters. Memoirs of the Museum of Victoria 58: 39-75.

Manuscript received 3 May 2001; accepted 1 August 2001. 